\title{
Historical and Confessional Study of the Peoples of the Middle Volga Region in the Kazan Theological Academy in the Second Half of the XIX - the Beginning of the XX Centuries
}

\author{
Ramil M. Valeev ${ }^{1}$, Mars Z. Khabibullin ${ }^{2}$, Elmira A. Saidasheva ${ }^{1} \&$ Leila A. Nurgalieva ${ }^{1}$ \\ ${ }^{1}$ Kazan (Volga Region) Federal University, Kazan, Russia \\ 2 Tatarstan Academy of Sciences, Institute of the Tatar Encyclopedia and Regional Studies, Kazan, Russia \\ Correspondence: Ramil M. Valeev, Kazan (Volga Region) Federal University, Kremlyovskaya Street 18, Kazan \\ 420008, Russia. E-mail: valeev200655@mail.ru; ram.valeev2016@yandex.ru
}

\author{
Received: April 14, 2015 Accepted: April 20, 2015 Online Published: April 27, 2015 \\ doi:10.5539/jsd.v8n4p104 URL: http://dx.doi.org/10.5539/jsd.v8n4p104
}

\begin{abstract}
The urgency of the problem under investigation is caused by the increased interest of modern researchers in the problems of interethnic and interconfessional interaction. The aim of the research consists in the objective representation of history of the missionary departments of the Kazan Theological Academy, the study of the educational, scientific and public work of its teachers and graduates, the analysis of scientific works on history, ethnography, language and culture of the Turkic, Finno-Ugrian and Mongolian peoples of the Middle Volga region in Kazan in the second half of the XIX - the beginning of the XX centuries. The Kazan Theological Academy was one of the largest religious and educational, missionary, ethnic and political institutions in Russia and, at the same time, one of the leading centers for studying history, culture, ethnography and language of the Turkic, Finno-Ugrian and Mongolian people in the second half of the XIX - the beginning of the XX centuries. The article deals with the scientific and educational activity of the only missionary departments of the Kazan Theological Academy in Russia (1842 - 1921), the contribution of such great teachers as N.I. Ilminsky, G.S. Sablukov, E.A. Malov, V.T. Timofeev, N.P. Ostroumov, M.A. Mashnov to the process of studying history, ethnography, language and culture of the peoples of the Middle Volga in Kazan in the second half of XIX - the beginning of XX centuries and to the covering of Islam and Christianity problems. The teachers of the Kazan Theological Academy made a great contribution to the historical, confessional, ethnic and political study of the Turkic, Finno-Ugrian and Mongolian people of Russia, and, moreover, they helped to preserve and develop the languages, form national education and promote integration of the people into a single cultural, educational and informational space of the Russian state. The professors of the missionary departments revealed and collected a huge amount of various materials (historical, linguistic and ethnographic) about the Tatars, the Maris, the Chuvashes, the Udmurts and the Mordvas, which are of great importance for the research of the sources of the modern international and interconfessional relations in the Republic of Tatarstan and the Russian Federation. The article can be useful for all people who are interested in the modern ethnic and political processes in the Russia Federation.
\end{abstract}

Keywords: the people of the Middle Volga, the Kazan Theological Academy, the missionary departments, ethnography, history

\section{Introduction}

The research of educational, scientific and social activity of teachers of the Kazan Theological Academy, the analysis of scientific papers on history, ethnography, language and culture of the Turkic, Finno-Ugrian and Mongolian people of the Middle Volga in Kazan in the second half of the XIX - early XX centuries is of great interest for modern scholars.

The phenomenon of interaction of Islam and Christianity particularly manifested itself in the Middle Volga region. After the Russian capture of the Kazan Khanate in 1552 they (the Russian government) pursued an active missionary policy towards ethnic groups and the peoples of the region. It's main aim was to baptize, russify and create a special system of education and institutes. Such Russian scientists as V.D. Dimitriyev (2002), F.G.Islayev (1999), L. A. Taymasov (2004) and western researchers - A. Bennigsen (1967), R. Geraci (2001), R. 
Pipes (1993), P. Werth (1997) highlighted the problem of the orthodox educational policy of the Russian state towards the Volga region people.

Since the establishment of the power of Moscow over a multinational population of the Kazan region and a special diocese (1555), the establishment of Orthodoxy was not only the missionary task of the church, but it was an important part of the state policy of the Russian tsar in the eastern remote areas of the empire (Taymasov, 2004).

\section{Methodological Framework}

Methods of this research are based on the use of the modern worldview ideas, gnosiological and logical principles. They play an important role in the study of the events, stages and directions of the formation of the missionary departments of the Kazan Theological Academy, which at the same time include researches of the teachers on history, ethnography, language and culture of the Turkic, Finno-Ugrian and Mongolian people of the Middle Volga region in Kazan in the second half of the XIX - the beginning of the XX centuries.

The methodological basis of the research was made by the general scientific methodological principles and methods applied in modern historical science. Our research is based on the following principles of the historical knowledge:

- historical method demands consideration of any historical phenomenon in its development and at the same time it consists in identifying of both specific features of each phenomenon, and factors causing it;

- the principle of integrity demands approach to the study of each phenomenon as to the system of the interrelated elements and examines the reasons determining them;

Methods of the systematic and comprehensive analysis helped to create a complete picture of the formation of the missionary departments of the Kazan Theological Academy, and from that interethnic and interconfessional relations in the region. Taking into account the specificity of the studied object statistical and sociological methods were involved.

It goes without saying that in the process of studying the history of the peoples of the region the comprehensive approach must be used. It assumes the use of knowledge from different scientific areas and disciplines, their synthesis and adaptation to the subject of the given research, which can help to identify the character and specificity of interaction of geographical, economical, social, historical, national and cultural conditions.

In the process of investigation the ethnogenetic approach was used. It allowed to define the nature of the relationship of ethnic groups; to learn the relations of "human-nature" with regard to concrete ethnic communities; to approach the solution of the ethnic problems with respect for the roots of these nations, their spiritual essence and national consciousness.

The investigation is carried out on the basis of the sociocultural approach, which assumes consideration of history through interaction of the society and culture. It is also necessary to mention the use of systematic, comparative and historical approaches. The use of all these approaches allowed us to reveal a cause-effect relationship and peculiarities of the interconfessional interaction of the non-Russian people of the Middle Volga region in the research made by the teachers of the Kazan Theological Academy.

\section{Results}

A variety of materials, especially archival records, show that in the Kazan Theological Academy in the second half of the XIX - early XX centuries a fundamental and original research on history, ethnography, language and culture of the Turkic, Finno-Ugrian and Mongolian people of the Middle Volga region was carried out in Kazan. The teachers of the Kazan Theological Academy made a great contribution to the historical, confessional and ethnopolitical study of the people of Russia, and, moreover, they helped to preserve and develop the languages, form national education and promote integration of the people into a single cultural, educational and informational space of the Russian state.

It should be noted that the historical, confessional and ethnopolitical study of the people and ethnic groups of Russia goes centuries back, and it is certainly connected with the large-scale missionary policy of the Russian state, used towards people of Russia in the second half of the XVI century.

It is known that such republics as Bashkortostan, Mari-El, Komi, Tatarstan, Udmurtiya and Chuvashiya are located in the European part of Russia, to be exact in the Middle Volga and Urals regions. It is obvious that the study of the origin of the people living here has a great scientific and practical value. Their past, the present and the future are inseparably linked with the history of Russia, as they are an integral part of modern ethnocultural processes. 
The Middle Volga and Urals regions have always been multiethnic and have been occupied by two different ethnic groups. The Western and the northern parts of this region are occupied by the people of the Finno-Ugrian group of the Ural language family such as the Maris, the Udmurts, the Mordvas, the Komi-Zirans and the Komi-Permyaks. As for the western and south-eastern parts of the region, they are occupied by the people of the Turkic group of the Altai language family, i.e. the Chuvashes, the Tatars and the Bashkirs.

The Kazan Khanate actually stopped existing in 1552 when troops of the Russian tsar Ivan IV conquered Kazan. Since that time, a new stage in the development of the people of the Volga and Urals regions begins. The main feature of the region is that by the time of its accession to Russia, only Kazan was founded by its people. In 1557 such cities as Cheboksar, then Laishev, Tetush, Samara and Ufa were built. These cities appeared since the resettlement of the Russians there, that's why they developed as Russian cities, and from the middle of the XIX century even in Kazan Russian population outnumbered the Tatars. This was the reason why ethno-consolidation processes in the region were not fully completed. In the past only the Kazan Tatars had the statehood, but after accession to the Moscow Russia, like earlier left groups of the Mishars, they quickly adapted to new conditions, having joined the long process of ethnocultural assimilation. Little resistance to Russian expansion in the Urals region was shown by the Islamized Bashkirs. All other ethnic groups didn't resist the accession to the Moscow Russia, and as a result they were gradually accepting the orthodox religion. This process in general had a positive impact on their further ethnocultural development. Their close communication with the Russians, which often lead to mixed marriages, promoted progressive economic and cultural relations and universal acquisition of the Russian language, and in some areas it resulted in full language assimilation.

The accession of the Volga and Urals regions to Russia was followed by the national and colonial oppression, which was undertaken under the authority of the tsar. The diocese founded in Kazan carried out the Christianization of local population. Both the Orthodox Church and Russian landowners got large areas of land in the Middle Volga region. The local working population who preserved lands was obliged to pay yasak to the Imperial Treasury. Uprisings of the Volga region peasants and citizens were directed both against the Russian landowners and the local feudal lords. The friendship between the Russian people and the people of the Volga region grew and got stronger in the joint fight against the exploiters.

Social and political development of Russia in the XVI-XVIII centuries represents a difficult and contradictory process of consolidation of the Russian society. Events of the Troubles Time, popular movements under I. I. Bolotnikov, S. T. Razin, E. I. Pugachev's leadership, reflected the inside of this process. On the other hand, during this period Russia developed as multiethnic and polyconfessional community. The last circumstance gave more dynamism to the above mentioned process. The interaction of the state and the ethnoconfessional societies included into it, first of all, was defined by the maintenance of the state policy. At the same time the local ethnic and religious specificity had a significant impact on the nature of these relationships.

In the second half of the XVI-XVIII centuries the imperial government took measures for the territorial, legal, tax and economic integration of the peoples of the Middle Volga and Urals regions into the social and political systems of the Russian state. The desire of the authorities to their religious unification faced deep-rooted religious traditions of the Finno-Ugrian, the Turkic and the Mongolian peoples. This interaction led to the strengthening of the religious factor in the political life of the region. It was particularly reflected in the rebel movements in the second half of the XVI-XVIII centuries.

In the first half of the XIX century the Kazan province became the center of the religious, national conflicts and mass disorders among ethnic groups. The Tatars played a noticeable role in this process. Under these circumstances the peoples of the region were violently baptized. The Russian government took active measures to change its policy and missionary activity. It is worth mentioning that a lot of educational institutions, religious and orthodox societies were set up which aim was to spread the Russian language and culture, levelling national and religious components and developing educational programs in theological seminaries and schools. The Kazan Theological Academy and the Brotherhood of St. Gury were the largest religious, ethno-political and educational centers in the Middle Volga region. The Kazan Theological Academy became a stronghold of the missionary activity in the Russian Empire in the XIX - early XX centuries. (Geraci, 2001).

In the second half of the XIX - early XX centuries the Kazan Theological Academy was a major religious, ethnic, political and educational institution in Russia. It was one of the leading centers for the study of history, ethnography, culture and language of the Turkic, the Finno-Ugrian and the Mongolian peoples. Researches of the teachers of the academy can still be found in the National Archives of the Republic of Tatarstan. They are dedicated to the culture and way of life, customs and traditions of the peoples of the Russian state. These sources are of great scientific importance for modern researchers (National archive of the Republic of Tatarstan, fund 10 
(fund of the Kazan Theological Academy); National archive of the Republic of Tatarstan, fund 968 (N. I. Ilminsky's fund, the professor of the Kazan Theological Academy); National archive of the Republic of Tatarstan, fund 967 (M. A. Mashanov's fund the professor of the Kazan Theological Academy).

Historical and confessional study of the people of Russia suggested that, teachers and graduates of the Kazan Theological Academy would conduct anti-Islamic discussions and propaganda, and it will also contribute to linguistic and spiritual integration of the people and the representatives of different faiths into single Russian space. According to the remark of the Russian Islamic scholar, professor of the University of Cologne M.A.Batunsky, teachers and students of anti-Muslim departments were the first professional missionaries and Islamic scholars in Russia (Batunsky, 1987).

One of the main factors of the opening of the Kazan Theological Academy in 1842 for the government and the higher church authority was «a desire to highlight a complex scientific issue, i.e. a question of " mixed ethnic groups " in Russia and develop reasonable measures to converge multimillion world of people of mixed ethnic groups with the indigenous population of the empire based on religion and culture» (the missionary department of the Kazan Theological Academy and internal mission in Russia (1906). Therefore, an important direction in the work of the academy was to study the language of the Turkic, the Finno-Ugrian, the Mongolian peoples of Russia and to conduct an active missionary work among them. For this purpose the only missionary department in Russia was established at the Kazan Theological Academy in 1854: «The adherents of different faiths and pagans who are in the Dioceses of the Kazan theological and educational district, of three clans: a) the Tatars, b) the people of the Mongolian tribe in) the Chuvashes, the Cheremisses, the Votyaks. All these tribes speak different languages and each of them has its own misconceptions about the faith, therefore: "1) It is necessary to open three parallel missionary departments in the Kazan Theological Academy for educating teachers of seminaries, and missionaries who can influence a) the Tatars, b) the Mongol tribe, and c) the Chuvashs, the Cheremisses, the Votyaks. 2) Only those students of higher and lower departments who want to be missionaries or mentors in the seminaries of the Kazan theological and educational district, and mostly pupils of those dioceses of the given tribes can study in these departments» (National Archives of the Republic of Tatarstan, fund 10, inventory of case 1. 827, 39 pieces of paper, the National Archives of the Republic of Tatarstan, fund 10, opis 1, delo 1324, 96-97 pieces of paper). Thus, the following missionary departments were opened in the Academy: 1) the anti-Muslim 2) the antidissenting 3) the anti-budhism and) the Cheremiss-Chuvashes.

In these departments of the Academy such subjects as ethnography, the languages of the Tatars, the Kyrgyzes, the Bashkirs, the Chuvashes, the Maris, the Udmurts, the Mordovas, the Mongols, the Buryats, the Kalmyks, the Ostiaks, the Samoyeds, the Yakuts, the Chukchis, the Tunguzes, the Manchurs, the Koreans, the Golds, the Gilyaks, the Koryaks and other people of Russia were taught.

The creation of the missionary departments contributed to the both integration of a large part of the non-Russian people of the region into a single Orthodox (Russian) cultural and educational space (especially the Mordovas, the Udmurts, the Maris, the Chuvashes) and widespread introduction of ethnic and national components into the educational process and the search for new and more effective pedagogical concepts which were necessary for the Orthodox cultural and religious enlightenment of non-Russian people.

The missionary departments of the Kazan Theological Academy, eventually turned into the effective center of Russian Orthodox missionary for aliens but not for the Tatars and the Bashkirs. They dealt with the foundations of the confessional education and Russification of the non-Russian people of Russia. Moreover they tried to create new forms, methods and ways of distribution of Orthodoxy among the Finno-Ugrian, the Turkic and the Mongol-speaking peoples and nationalities (Khabibullin, 2009).

The anti-Muslim department was in a special position among all missionary departments of the Academy. The Tatar factor was the reason of it. In this connection, the main activity of anti-Muslim department was to train specialists to conduct cultural, educational, religious and missionary work among the baptized Tatars. It was done to prevent them from returning to their previous religion (Islam), which in the first half of the XIX century began to acquire a mass character. While training missionaries special attention was paid to the restriction of an Islamic factor not only in a baptized and Tatar environments but also among the Finno-Ugrian people of the Volga, Urals and Siberia regions. For this purpose such subjects as "Muhammad's story", "Muhammad's faith", "pedagogics", the "Tatar" and "Arab" languages were taught rather in details to the students of the academy (Gvozdev, 1868). In the course of training much attention was also paid to the study of the original sources of Islam (the Quran, Sunnah, hadis, etc.) and the Tatar national traditions that was considered necessary for a complex (system) disclosure of ethnic character, habits and customs of the Tatars, and their mentality. Among other tasks of anti-Muslim missionary department there was also a professional (scientific) studying of history, 
language, culture and religious beliefs of the people of the called regions for the purpose of the development of the new orthodox cultural and educational concept necessary for levelling of national and religious features of the people and creation of a special missionary system of education.

Thanks to these innovative changes teachers and graduates of the Kazan Theological Academy managed to organize an effective system of religious education of some ethnic groups living in the Volga and Urals regions (the Maris, the Mordvas, the Udmurts, the Chuvashes) on the basis of N. I. Ilminsky's system in the second half of the XIX - the beginning of the XX centuries. The main feature and originality of this system was in the use of the native language of the non-Russian people both in the educational sphere and in the process of cultural and religious education of aliens. Afterwards it was used to create a lot of missionary schools of the Brotherhood of St. Gury.

In the academy teachers of anti-Muslim and Cheremiss-Chuvash departments were actively engaged in the study of history, culture, ethnography and language of the people of the Middle Volga region. It is necessary to note, that N. I. Ilminsky (1822-1891), G. S. Sablukov (1804-1880), E. A. Malov (1835-1918), V. T. Timofeev (1836-1895), N. P. Ostroumov (1846-1930), M. A. Mashanov (1852-1924), V.P. Vishnevsky (1804-1885) made a great contribution to the study of the people and ethnic groups of the Volga and Urals regions.

Russian historiography is rich in the works of R.M.Valeev, A. A. Khabibullin, R. M. Mukhametshin, A. V. Zhuravsky, etc. (Valeev, 1993; Khabibullin, 2005; Mukhametshin, 2003; Zhuravsky, 1999) which reflect the history of the missionary departments of the Kazan Theological Academy, the heritage of its teachers, and problems of the people of the Middle Volga region. Western researchers - Paul Werth, Robert Geraci, etc. - also paid much attention to the history of the Kazan Theological Academy and scientific activities of its teachers (Geraci, 2001; Werth, 1997).

Historical and confessional study of the people of the Middle Volga region was carried out by the famous orientalist, educator and missionary N. I. Ilminsky. The investigation was focused on the study of history, culture and language of the Turkic people. Ilminsky's works contain interesting information about national literature, history, culture and language of the people of the Russian Empire (Ilminsky, 1883; Ilminsky, 1887).

E. A. Malov, a teacher of the Kazan Theological Academy, carried out activities aimed at the study of history, ethnography and language of the people of the Middle Volga region. The scientific library of the Kazan (Volga) Federal university named after N. I. Lobachevsky contains dozens of scientific works and missionary diaries of this bright representative of the Kazan theological school. P.V.Znamensky wrote that his "nature, is deliberately created for a practical missionary work; besides he is the historian of mission and the skillful observer of customs, intellectual and religious concepts of the Tatars" (Znamensky, 1892). E. A. Malov's practical activities were reflected in the orientation of his literary and scientific compositions which were mainly polemic and anti-Muslim (Malov, 1885, 1891).

It goes without saying that a special place among teachers of the missionary departments of the Kazan Theological Academy is taken by the linguist, the translator and the public figure V. T. Timofeev. He made a great contribution to the education of the baptized Tatars, he opened schools for them and began to form the educated class of the Kryashens (Khabibullin, 2012).

N. P. Ostroumov, another teacher of the Kazan Theological Academy, also became interested in the life of the people of the Volga region. In Kazan he did a research on history, ethnography and language of the Tatars, though the considerable part of his heritage is connected with the study of history, ethnography and language of the Muslim people of Central Asia (Ostroumov, 1892).

The original facts and materials on history, culture and ethnography of the people of the Middle Volga region can be found in M. A. Mashanov's works. His researches are of huge value for the reconstruction of the religious shape of the Tatars in the second half of the XIX - the beginning of the XX centuries, they help to see the relationship of the Tatar and Russian people, the life and customs of the Chuvashes, the Maris and other ethnic groups of Volga region (Mashanov, 1875); Mashanov, M. A. The report on the trip to the village Nikiforovo of the Mamadyshsky district for the persuasion of those who refused Christianity. It was on 27 October 1881 (National archive of the Republic of Tatarstan, fund 967, inventory 1, delo 8, 18 pieces of paper).

The teachers of the Cheremiss-Chuvash missionary department, opened in the Kazan Theological Academy in 1854, were engaged in the study of history, ethnography and language of the Chuvashes and the Maris. The archpriest V.P. Vishnevsky was the only teacher who knew the Chuvash and Mari languages very well and did research on history of these ethnic groups. However the Cheremiss-Chuvash missionary department didn't exist for a long, and it was closed in 1856. 
The teachers of the missionary departments of the Kazan Theological Academy paid close attention to the study of history, ethnography and language of the peoples of Russia and training of national teachers. It is also worth noting that the Teacher's seminary was opened in 1870 with the active participation of N. I. Ilminsky. Later in 1889 two-year courses were opened at the Kazan Theological Academy where much attention was paid to the study of language, history, ethnographies and cultures of the peoples of the Middle Volga region: "In the missionary courses sciences of both missionary departments are taught: I) of the Tatar language a) history and reproof of Islam, b) ethnography of the Tatars, the Kyrgyzes, the Bashkirs, the Chuvashes, the Cheremisses, the Votyaks, the Mordovas, c) history of spreading Christianity among the marked tribes" (Considerations about opening of two-year missionary courses at the Kazan Theological Academy, 1889).

In the second half of the XIX - the beginning of the XX centuries the Kazan Theological Academy was one of the largest scientific and educational institutions in matters related to the study of history, culture, ethnography, language, religious beliefs of the people of Central Volga region in Russia. The teachers of the missionary departments of the academy revealed and collected a huge amount of various materials (historical, linguistic, ethnographic) about the Tatars, the Maris, the Chuvashes, the Udmurts, the Mordvas which is of great importance for the investigation of the sources of the modern international and interconfessional relations in the Republic of Tatarstan and the Russian Federation.

The teachers of the Kazan Theological Academy made a significant contribution to the historical, confessional, ethnic and political study of the Turkic, Finno-Ugrian and Mongolian people of Russia, they also helped to preserve and develop the languages, form national education and promote integration of the people into a single cultural and educational space of the Russian state.

\section{Discussions}

Both Russian and foreign experts were involved in the investigation of the issue. However the analysis of the people from this point of view has been given for the first time in the article.

\section{Conclusion}

The significance and urgency of the topic are defined by the increasing interest from governmental structures and society in general to the problems of regulation of the interethnic and interconfessional relations, and to the protection of the rights of small indigenous ethnic groups and preservation of a national cultural diversity. With the integration of large areas of the Middle Volga into the Russian State from the second half of the XVI century became a starting point for the formation of the Russian multiethnic and polyconfessional space. The people of Russia became a special subject of studying of scientific organizations and societies. In the second half of XIX the beginning of the XX centuries. In the second half of the XIX - the beginning of the XX centuries the Kazan Theological Academy was one of the largest scientific and educational institutions in matters related to the study of history, culture, ethnography, language, religious beliefs of the people of Central Volga region in Russia. The teachers of the missionary departments of the academy revealed and collected a huge amount of various materials (historical, linguistic, ethnographic) about the Tatars, the Maris, the Chuvashes, the Udmurts, the Mordvas which is of great importance for the investigation of the sources of the modern international and interconfessional relations in the Republic of Tatarstan and the Russian Federation.

\section{Recommendations}

The article can be useful for all people who are interested in modern ethnopolitical processes in the Russian Federation, as well as it can be used when writing some generalizing works on history of the peoples of Russia and when delivering lectures on national history.

\section{Acknowledgments}

The work is performed according to the Russian Government Program of Competitive Growth of Kazan Federal University.

\section{References}

Batunsky, M. (1987). Russian missionary literature on Islam. Zeitschrift fur Religions und Geistesgeschichte, 39(3), 253-266. http://dx.doi.org/10.1163/157007387X00219

Bennigsen, Alexandre and Chantal Lemercier-Quelquejay. (1967). Islam in the Soviet Union. New York: Fredrick A. Praeger Publishers.

Dimitriev, V. D. (2002). Prosvetitel' chuvashskogo naroda I.Ja.Jakovlev. Cheboksary.

Geraci, R. (2001). Window on the East: National and Imperial Identities in Late Tsarist Russia. USA: University 
of Virginia: 91.

Habibullin, A. A. (2005). Narody Srednego Povolzh'ja i Priural'ja: istorija i kul'tura. Kazan'.

Habibullin, M. Z., \& Vagazova, R. M. (2012). Obshhestvennaja i pedagogicheskaja dejatel'nost' Vasilija Timofeevicha Timofeeva (1836-1895 gg.). «Nauka i biznes: puti razvitija», 6(12), 41-44.

Il'minskij, N. I. (1883). Iz perepiski po povodu primenenija russkogo alfavita k inorodcheskim jazykam. Kazan'.

Il'minskij, N. I. (1887). Kazanskaja kreshheno-tatarskaja shkola. Materialy dlja istorii prosveshhenija tatar. Kazan'.

Islaev, F. G. (1999). Pravoslavnye missionery v Povolzh'e. Kazan'.

Malov, E. A. (1885). Svedenija o misharjah. Jetnograficheskij ocherk. Kazan'.

Malov, E. A. (1891). O kreshhenyh tatarah (iz missionerskogo dnevnika. Kazan'.

Mashanov, M. A. (1875). Zametka o religiozno-nravstvennom sostojanii kreshhenyh tatar Kazanskoj gubernii Mamadyshskogo uezda. Kazan'.

Mashanov, M. A. (1881). Otchet o poezdke v derevnju Nikiforovo Mamadyshskogo uezda dlja uveshhanija otpavshih ot hristianstva. 27 oktjabrja 1881 goda (Nacional'nyj arhiv Respubliki Tatarstan, fond 967, opis' 1, delo 8, 18 listov).

Missionerskoe otdelenie pri Kazanskoj duhovnoj akademii i vnutrennjaja missija v Rossii. Cerkovno-obshhestvennaja zhizn'. 1906, 18: 634.

Muhametshin, R. M. (2003). Tatary i islam v XX veke. Kazan'.

Nacional'nyj arhiv Respubliki Tatarstan, fond 10 (fond Kazanskoj duhovnoj akademii).

Nacional'nyj arhiv Respubliki Tatarstan, fond 10, opis' 1, delo 1324.

Nacional'nyj arhiv Respubliki Tatarstan, fond 10, opis' 1, delo 827.

Nacional'nyj arhiv Respubliki Tatarstan, fond 967 (fond M.A.Mashanova - professora Kazanskoj duhovnoj akademii).

Nacional'nyj arhiv Respubliki Tatarstan, fond 968 (fond N.I.Il'minskogo - professora Kazanskoj duhovnoj akademii).

Ostroumov, N. P. (1876). Pervyj opyt slovarja narodno-tatarskogo jazyka po vygovoru kreshhenyh tatar Kazanskoj gubernii. Kazan'.

Ostroumov, N. P. (1892). Tatarsko-russkij slovar'. Kazan'.

Pajps, R. (1993). Rossija pri starom rezhime. Per. s angl. M.: Nezavisimaja gazeta.

Soobrazhenija ob otkrytii dvuhgodichnyh missionerskih kursov pri Kazanskoj duhovnoj akademii. (1889). Kazan': 1-8.

Tajmasov, L. A. (2004). Hristianskoe prosveshhenie nerusskih narodov i jetnokonfessional'nye processy v Srednem Povolzh'e v poslednej chetverti XVIII - nachale XX veka (Dissertacija doktora istoricheskih nauk). Cheboksary: 3-4.

Tajmasov, L. A. (2004). Pravoslavnaja cerkov' i hristianskoe prosveshhenie narodov Srednego Povolzh'ja vo vtoroj polovine XIX - nachale XX veka. Cheboksary.

Valeev, R. M. (1993). Iz istorii kazanskogo vostokovedenija serediny-vtoroj poloviny XIX v.: Gordij Semenovich Sablukov - tjurkolog i islamoved. Kazan'.

Werth, P. W. (1997). Subjects for Empire: Orthodox mission and imperial governance in the Volga-Kama region, 1825-1881. USA: University of Michigan.

Zhuravskij, A. V. (1999). Kazanskaja duhovnaja akademija na perelome jepoh. 1884-1921 gg. (Dissertacija kandidata istoricheskih nauk). Moskva.

Znamenskij, P. V. (1892). Na pamjat' o Nikolae Ivanoviche Il'minskom. K dvadcatipjatiletiju Bratstva svjatitelja Gurija. Kazan': 156-161. 


\section{Copyrights}

Copyright for this article is retained by the author(s), with first publication rights granted to the journal.

This is an open-access article distributed under the terms and conditions of the Creative Commons Attribution license (http://creativecommons.org/licenses/by/3.0/). 